\title{
The repeatability of nonbronchoscopic bronchoalveolar lavage differential cell counts
}

\author{
T.J. Warke*,\#, S. Kamath*,\#, P.S. Fitch*,\#, V. Brown", M.D. Shields*, M. Ennis ${ }^{\#}$
}

The repeatability of nonbronchoscopic bronchoalveolar lavage differential cell counts. T.J. Warke, S. Kamath, P.S. Fitch, V. Brown, M.D. Shields, M. Ennis. (C)ERS Journals Ltd 2001.

ABSTRACT: Airway inflammation in children can be assessed by nonbronchoscopic bronchoalveolar lavage (BAL). Little is known about the repeatability of cell counts in the BAL obtained.

Children ( $n=43)$ attending for elective surgery were studied. Cell counts were obtained following a nonbronchoscopic lavage. Two samples were obtained with either: 1) the catheter wedged in the same position $(n=21)$ or 2$)$ the catheter reinserted and wedged again $(n=22)$. Slides $(n=30)$ from nonbronchoscopic lavage samples were selected at random and two independent observers counted 500 cells on each slide on two occasions. The repeatability of the lavage sampling and cell counting was assessed for different cell types.

The inter- and intra-observer repeatability for the differential cell counting demonstrated that there was good repeatability for all cell types except lymphocytes (interobserver: Lin's concordance coefficient 0.42 ; repeatability coefficient 0.66 ). Quantification of eosinophil (\%) was highly repeatable using either method (Lin's concordance coefficient 1) $0.99,2) \quad 0.95$; repeatability coefficient 1) $0.58,2$ ) 1.36 ).

Nonbronchoscopic lavage is a repeatable technique for the quantification of eosinophils. Variation in the sampling method can be reduced by taking two separate samples and averaging the differential cell counts. Furthermore, increasing the number of cells counted should ensure accurate quantification of lymphocytes.

Eur Respir J 2001; 18: 1009-1012.
Depts of *Child Health and ${ }^{\#}$ Clinical Biochemistry, The Queen's University of Belfast, Belfast, Northern Ireland, UK.

Correspondence: M. Ennis, Dept of Clinical Biochemistry, The Queen's University of Belfast, Institute of Clinical Science, Grosvenor Road, Belfast BT12 6BJ, Northern Ireland, UK. Fax: 442890236143

Keywords: Bronchoalveolar lavage differential cell count

nonbronchoscopic bronchoalveolar lavage

repeatability

Received: January 82001

Accepted after revision June 292001

The study was supported by the following funding sources: Research and Development Office for Northern Ireland; Royal Belfast Hospital for Sick Children; National Asthma Campaign, UK.
Nonbronchoscopic lavage is a safe technique for obtaining bronchoalveolar lavage (BAL) samples, for research purposes, from children who are being intubated for elective surgical procedures [1]. There are no reports on the repeatability of the cell counts obtained, as highlighted by the recent European Respiratory Society (ERS) Taskforce paper [2]. The aim of the present study was to assess the repeatability of cellular differentials counted on samples obtained by nonbronchoscopic BAL with sampling performed in the same or potentially different areas.

\section{Methods}

\section{Study subjects}

Subjects ( $\mathrm{n}=43$, aged $3-12 \mathrm{yrs}$, mean $9.6 \mathrm{yrs}, 27$ males) attending the Royal Belfast Hospital for Sick Children (Belfast, Northern Ireland, UK), for an elective surgical procedure, for a noninflammatory condition were studied. Of these, 23 were healthy normal subjects, eight were nonasthmatic atopics and 12 were atopic asthmatics. All children were clinically well and free from current respiratory infection. Written informed consent was obtained from the parents of all subjects for the research BAL procedure and the study was approved by the Research Ethics Committee of the Queen's University of Belfast.

\section{Lavage procedure and sampling}

Nonbronchoscopic BAL was performed as previously described [1, 3]. In brief, after the induction of anaesthesia and intubation, a sterile, size 8 French Gauge neonatal suction catheter was passed through the endotracheal tube and wedged in a distal airway. Saline $(20 \mathrm{~mL})$ was instilled and immediately aspirated. The subjects underwent a second $20 \mathrm{~mL}$ lavage with either: 1) the catheter remaining wedged in the same position (method $1, n=21$ ), or 2 ) with a second catheter wedged after removal of the first (method 2, $\mathrm{n}=22$ ).

Total cell counts were performed using a modified Neubauer haemocytometer (BDH Ltd, Poole, UK) and differential cell counting was performed using the glass coverslip method [1,3]. Coverslips were fixed and stained with Diff-Quik $\AA$ (Baxter Healthcare Ltd, Compton, UK) with at least 500 cells counted $\cdot$ coverslip $^{-1}$. 
Table 1. - Intra-observer repeatability for cell counting

\begin{tabular}{|c|c|c|c|c|c|}
\hline Observer and cell type & d (bias) & Mean (range) $\%$ & $95 \%$ Limits of agreement & $\mathrm{Rc}_{\mathrm{c}}$ & Repeatability coefficient \\
\hline \multicolumn{6}{|l|}{ Observer 1} \\
\hline Eosinophils & 0.03 & $1.22(0-16)$ & $-0.36-0.42$ & 0.99 & 0.38 \\
\hline Macrophages & 0.04 & $71.14(27.6-98.9)$ & $-3.70-3.78$ & 0.99 & 3.68 \\
\hline Neutrophils & 0.11 & $10.27(0-37.56)$ & $-1.12-1.34$ & 0.99 & 1.23 \\
\hline Epithelial & -0.30 & $17.40(0.4-56.4)$ & $-3.56-2.96$ & 0.99 & 3.26 \\
\hline Lymphocytes & -0.07 & $0.17(0-1.6)$ & $-0.38-0.25$ & 0.91 & 0.34 \\
\hline \multicolumn{6}{|l|}{ Observer 2} \\
\hline Eosinophils & 0.22 & $1.24(0-15.6)$ & $-0.89-1.32$ & 0.98 & 1.17 \\
\hline Macrophages & -0.79 & $70.62(26.6-99)$ & $-7.04-5.46$ & 0.99 & 6.33 \\
\hline Neutrophils & 0.26 & $10.11(0.19-38.59)$ & $-4.42-4.95$ & 0.98 & 4.63 \\
\hline Epithelial & 0.60 & $17.93(0-59.6)$ & $-5.36-6.55$ & 0.99 & 5.97 \\
\hline Lymphocytes & -0.02 & $0.09(0-0.97)$ & $-0.43-0.40$ & 0.56 & 0.41 \\
\hline
\end{tabular}

Rc: Lin's concordance coefficient; d: mean difference; mean: mean of the paired values.

\section{Repeatability}

Repeatability was calculated by comparing the differential cell counts obtained from the two lavages for both methods (methods 1 and 2). In addition, two independently-trained observers performed differential cell counts on 30 slides, counting at least 500 cells $\cdot$ slide ${ }^{-1}$, on two separate occasions. The observers were blinded from their original cell count for each slide. The intra-observer repeatability was calculated by comparing the differential cell counts performed on two occasions by one observer (same slides, same observer). The interobserver repeatability was calculated by comparing the differential cell counts of both observers (same slides, two observers).

\section{Statistical analyses}

Reproducibility (method or observer agreement) and repeatability (same observer, same slide) analyses were approached in the same way. Using sets of paired results the $95 \%$ repeatability coefficient was calculated (this indicates the maximum difference that is likely to occur between two measurements if there is no bias) [4]. In addition, the mean of the differences (d) between two measurements (bias) and the 95\% limits of agreement (95\% LOA) were calculated [5]. The $95 \%$ LOA was $d \pm 1.96$ (SD of $d$ ). Lin's concordance coefficient, Rc, was also employed [6]. This value is considered complementary to the $95 \%$ LOA [7] and combines measures of both precision and accuracy to determine whether the observed data deviate significantly from the line of perfect concordance (i.e. line of identity). Whether repeatability or agreement is excellent, moderate or poor is a subjective decision. To aid this judgement, the average of the repeated measurements has been tabulated. Excellent repeatability/agreement was defined as $\mathrm{Rc}_{\mathrm{c}}$ $>0.90$, satisfactory as $R_{c} 0.6-0.9$ and unsatisfactory, $\mathrm{R}_{\mathrm{c}}<0.6$. As any correlation, including Lin's concordance correlation will depend on the analytical range studied, the range of the means of paired values is reported.

\section{Results}

The mean difference and average cell percentage counts of different cell types with their ranges, 95\% limits of agreement, repeatability coefficient and $\mathrm{Rc}_{\mathrm{c}}$ are shown for paired samples assessing intra- and interobserver repeatability and agreement between the different methods, in tables 1,2 and 3 respectively.

\section{Discussion}

The results for intra-observer repeatability in differential cell counting (table 1) demonstrate excellent repeatability for eosinophils, macrophages, neutrophils and epithelial cells. With observer 1, there was also excellent, but slightly reduced, repeatability for lymphocyte percentage cell counts. With observer 2 , however, there was poor lymphocyte repeatability. The interobserver repeatability in cell counting demonstrated excellent repeatability for eosinophils,

Table 2. - Interobserver repeatability for cell counting

\begin{tabular}{lcccc}
\hline Cell type & $\mathrm{d}$ (bias) & Mean (range) $\%$ & $\begin{array}{c}95 \% \text { Limits of } \\
\text { agreement }\end{array}$ & $\begin{array}{c}\text { Rc } \\
\text { coefficient }\end{array}$ \\
\hline Eosinophils & -0.02 & $1.23(0-16)$ & $-0.61-0.57$ & 0.99 \\
Macrophages & 0.51 & $70.88(26.6-99)$ & $-4.94-5.97$ & 0.99 \\
Neutrophils & 0.16 & $10.19(0-38.59)$ & $-3.58-3.90$ & 0.99 \\
Epithelial & -0.54 & $17.67(0-59.6)$ & $-4.69-3.61$ & 0.99 \\
Lymphocytes & 0.08 & $0.13(0-1.6)$ & $-0.57-0.74$ & 4.69 \\
\hline
\end{tabular}

Rc: Lin's concordance coefficient; d: mean difference; mean: mean of the paired values. 
Table 3. - Repeatability of lavage methods 1 and 2

\begin{tabular}{|c|c|c|c|c|c|}
\hline Method and cell type & d (bias) & Mean (range) \% & $\begin{array}{l}95 \% \text { Limits of } \\
\text { agreement }\end{array}$ & $\mathrm{Rc}$ & $\begin{array}{c}\text { Repeatability } \\
\text { coefficient }\end{array}$ \\
\hline \multicolumn{6}{|l|}{ Method 1} \\
\hline Eosinophils & 0.09 & $0.91(0-12.54)$ & $-0.47-0.66$ & 0.99 & 0.58 \\
\hline Macrophages & 6.04 & $79.54(22.24-98.05)$ & $-30.72-42.79$ & 0.29 & 37.76 \\
\hline Neutrophils & -6.48 & $6.11(0.18-73.69)$ & $-35.65-22.70$ & 0.21 & 31.18 \\
\hline Epithelial & -1.02 & $11.49(0-53.4)$ & $-22.80-20.76$ & 0.67 & 21.35 \\
\hline Lymphocytes & 1.37 & $1.97(0-11.13)$ & $-3.64-6.38$ & 0.21 & 5.58 \\
\hline \multicolumn{6}{|l|}{ Method 2} \\
\hline Eosinophils & -0.07 & $1.40(0-8.68)$ & $-1.45-1.31$ & 0.95 & 1.36 \\
\hline Macrophages & 6.15 & $60.79(21.1-95.96)$ & $-41.97-54.26$ & 0.43 & 48.53 \\
\hline Neutrophils & -4.49 & $7.44(0.09-69.5)$ & $-41.5-32.53$ & 0.23 & 37.22 \\
\hline Epithelial & -1.88 & $29.86(0.2-76.5)$ & $-39.94-36.18$ & 0.67 & 37.37 \\
\hline Lymphocytes & 0.26 & $0.45(0-3.3)$ & $-1.74-2.25$ & 0.10 & 2.01 \\
\hline
\end{tabular}

Rc: Lin's concordance coefficient; d: mean difference; mean: mean of the paired values; Method 1: two lavages with one catheter wedged in same position; Method 2: two lavages with two separate catheters.

macrophages, neutrophils and epithelial cells. Interobserver repeatability for lymphocytes was poor. This may be due to low lymphocyte numbers. The difference of a few cells would have a major impact on repeatability when only 500 cells are counted. Therefore, to accurately quantify lymphocyte percentages, it may be necessary to count more cells overall. Consistent with these data, good interobserver repeatability for differential cell counting on adult BAL samples has been reported [8] and for induced sputum samples found for macrophages, eosinophils [9] and neutrophils, but not lymphocytes $[10,11]$.

The results obtained using method 1 indicate excellent agreement between the first and second BAL samples for eosinophils, satisfactory agreement for epithelial cells but poor agreement for lymphocytes, neutrophils and macrophages. As the catheter was wedged in the same position and sequential lavages performed, the differences between the two samples may be explained by considering the first lavage as a bronchial sample, whereas the second was an alveolar sample. Differences between bronchial and alveolar samples have been shown in adults [12, 13] and children [14] when taking sequential lavages from the same location and processing the samples separately. GRIGG et al. [14] found that the alveolar samples had a higher percentage of macrophages and lower percentage of neutrophils compared to the bronchial samples. The present results showed a similar trend but the difference was not significant.

Method 2 examined the repeatability of the whole procedure as two entirely separate lavages using different catheters were performed on the same individual. The sites of lavage may be different but, as nonbronchoscopic lavage is a blind procedure, the site of wedging cannot be confirmed. Excellent repeatability and agreement were found between the two samples for eosinophils, satisfactory for epithelial cells and poor for other cell types. Studies in adults with BAL samples obtained using fibreoptic bronchoscopy have demonstrated good repeatability of the differential cell count when BAL is performed on the same subjects on different occasions [15] and from different sites within the lungs [16].

PUROKIVI et al. [17] found that the repeatability of differential cell counts from induced sputum samples taken 48-h apart was highly reproducible except for lymphocytes. However, their 95\% LOA for eosinophils were in the region of $-300-300 \%$. This is in contrast to the present findings for eosinophils where the 95\% LOA were $-1.45-1.31 \%$ (method 2). In children, the reproducibility of eosinophil counts from induced sputum samples taken 10 days apart had LOA of 0.68-2.4 fold [9], which is comparable to the present findings with BAL.

Nonbronchoscopic lavage is a useful method to gain information from children with asthma and normal subjects, with particular reference to eosinophilic inflammation. The data from the present study show that this technique is highly repeatable for quantifying eosinophil percentages and most other cell types. As most of the variation is attributable to the sampling method rather than the cell counting, it is recommended that two separate samples are taken and the cell counts averaged to reduce the inherent variation. In the case of lymphocytes, repeatability may be improved by counting 2,000-5,000 cells, as recommended for mast cells [1,3]. This method of lavage is a clinically useful and repeatable tool in this context.

\section{References}

1. Heaney LG, Stevenson EC, Turner G, et al. Investigating paediatric airways by nonbronchoscopic lavage: normal cellular data. Clin Exp Allergy 1996; 26: 799-806.

2. de Blic J, Midulla F, Barbato A, et al. Bronchoalveolar lavage in children. Eur Respir $J$ 2000; 15: 217-231.

3. Stevenson EC, Turner G, Heaney LG, et al. Bronchoalveolar lavage findings suggest two different forms of childhood asthma. Clin Exp Allergy 1997; 27: 10271035.

4. Bland JM, Altman DG. Measurement error. BMJ 1996; 313: 744 .

5. Bland JM, Altman DG. Statistical methods for assessing agreement between two methods of clinical measurement. Lancet 1986; 1: 307-310. 
6. Lin LI. A concordance correlation coefficient to evaluate reproducibility. Biometrics 1989; 45: 255-268.

7. Steichen TJ, Newton HJ. Concordance correlation coefficient. The Stata Technical Bulletin Reprints. College Station, TX, Stata Press, 1999; pp. 137-145.

8. Banks DE, Morgan JE, Deshazo RD, et al. Reliability of cell counts and protein determinations in serial bronchoalveolar lavage procedures performed on healthy volunteers. Am J Med Sci 1990; 300: 275-282.

9. Wilson NM, Bridge P, Spanevello A, Silverman M. Induced sputum in children: feasibility, repeatability, and relation of findings to asthma severity. Thorax 2000; 55: 768-774.

10. Ward R, Woltmann G, Wardlaw AJ, Pavord ID. Between-observer repeatability of sputum differential cell counts. Influence of cell viability and squamous cell contamination. Clin Exp Allergy 1999; 29: 248 252.

11. Spanevello A, Migliori GB, Sharara A, et al. Induced sputum to assess airway inflammation: a study of reproducibility. Clin Exp Allergy 1997; 27: 1138-1144.

12. Van Vyve T, Chanez P, Lacoste JY, Bousquet J, Michel FB, Godard P. Comparison between bronchial and alveolar samples of bronchoalveolar lavage fluid in asthma. Chest 1992; 102: 356-361.

13. Rennard SI, Ghafouri $\mathrm{M}$, Thompson $\mathrm{AB}$, et al. Fractional processing of sequential bronchoalveolar lavage to separate bronchial and alveolar samples. $\mathrm{Am}$ Rev Respir Dis 1990; 141: 208-217.

14. Grigg J, Arnon S, Silverman M. Fractional processing of sequential bronchoalveolar lavage fluid from intubated babies. Eur Respir J 1992; 5: 727-732.

15. Ettensohn DB, Jankowski MJ, Redondo AA, Duncan PG. Bronchoalveolar lavage in the normal volunteer subject. 2. Safety and results of repeated BAL, and use in the assessment of intrasubject variability. Chest 1988; 94: 281-285.

16. Limper AH, Specks U, Brutinel WM, Martin WJ, Rohrbach MS. Interlobar variation in the recovery of bronchoalveolar lavage fluid, cell populations, and angiotensin-converting enzyme in normal volunteers. J Lab Clin Med 1993; 121: 785-791.

17. Purokivi M, Randell J, Hirvonen MR, Tukiainen H. Reproducibility of measurements of exhaled NO, and cell count and cytokine concentrations in induced sputum. Eur Respir J 2000; 16: 242-246. 